\title{
TRÊS SONETOS PARA O BRASIL CONTEMPORÂNEO
}

Thiago Gonçalves Souza ${ }^{1}$

1

Pra se pôr contra toda essa loucura,

será bastante apenas paciência?

Haverá quem é são e que atura

tamanha verborreia de demência?

"Vigiai, que é global a ditadura!

É gayzista-marxista a influência!

Destrói a branca, sacra Armadura

da Pátria, da Família e da Decência!"

Com tais ideias, podres e azedias,

é que ela quer reger os nossos dias

(ai, frutos de uma queda a mais sinistra)...

Batizada no Templo da Asneira,

nos leva a tal Estado de leseira

a Besta que o governa e que o ministra!

2

A Besta que governa e que ministra

tem feito o dia a dia insuportável

com cada uma inimaginável

atitude absurda e mais sinistra!

Quem é que tal doidice administra

\footnotetext{
${ }^{1}$ Doutor em Literatura Comparada e Teoria Literária pela Universidade do Estado do Rio de Janeiro (UERJ). Professor de Língua Portuguesa e Literatura.
} 
e ainda segue ileso, inquebrantável?

É sangue de barata, imperturbável,

ou já perdeu o senso e não registra!

Aí está; mas como foi possível?

Aí estando, como continua?

Continuando, a gente se habitua?

Vivendo nesse tempo inconcebível,

só peço é muita força de vontade

na luta pra guardar a sanidade!

3

Na luta pra guardar a sanidade,

sinto já os desgastes da defesa;

sinto que se arruína a fortaleza

erguida pra barrar a ruindade...

Sempre, sempre uma nova atrocidade

nos assalta e golpeia com baixeza!

Vem e nos rouba a paz mais a leveza

e os dias nos arrasa em sujidade!

Sem trégua, a toda hora, a cada instante, um baque, depois outro - é sufocante!

Não respiro e me sinto adoecer...

Quem vem prever o fim de tanta agrura?

Todo o mundo odiento se afigura...

E eu quero é que vá tudo se foder! 